\title{
Appraisal of arid land status: a holistic assessment pertains to bio-physical indicators and ecosystem values
}

\author{
Manish Mathur ${ }^{1,2^{*}}$ and S. Sundaramoorthy ${ }^{1}$
}

\begin{abstract}
Background: Appraisal of arid land status is very crucial one to know the extent and factors associated with their degradation. Previous studies from arid regions are mostly qualitative in nature (indicator assessment like good, moderate, severe, and very severe) and generally overlooked the significance of temporal fluctuation.

Methods: In this study, the temporal status of 12 Indian arid lands was accessed by using a new integrated approach that includes attributes like relative converge score (RCS), herbaceous component score (HCS), soil quality index Modified $_{\text {. }}$ $(\mathrm{SQl})$, ecosystem monitoring value (EMV), and a modified bare patch index. From each land, data were collected during three seasonal events (pulse, inter-pulse, and non-pulse), and thus, status was evaluated with 36 observations. Data were analyzed by using frequency distribution, principal component analysis (PCA), student $t$ test, and regression technique.

Results: RCS and HCS were recorded minimum $(0.005,0.65)$ during non-pulse event and maximum $(0.36,1.79)$ during pulse event respectively. With this approach, multi-directional temporal status of lands identified that were grouped into lower (7), moderate (14), high (12), and very high (3) quality lands.

Conclusion: This integrated study suggested that in arid regions, although rainfall triggers plant community composition, however, sole utilization of this parameter is unable to portray the true status of lands, and other physical (soil) and biotic (livestock and other anthropogenic) parameters are equally important and influential during other events.
\end{abstract}

Keywords: Vegetation status, Relative coverage score, Soil quality, Land status, Ecosystem monitoring value

\section{Introduction}

Land degradation pertains to three attributes, viz, ecosystem services, disturbances, and the resilient properties of the land (UNEP 2007). Further, Zero Net Land Degradation concept of UNCCD (2012) pointed out toward the degradation and the land restoration capabilities thresholds, applicable to all types of land use. Previous studies indicated that eight parameters or tools, viz, climatic, soil, vegetation, hydrological, livestock, anthropogenic pressure, ecosystem services (functional, supportive, and provisional), and remote sensing, and GIS are frequently utilized for land status assessment.

\footnotetext{
*Correspondence: eco5320@gmail.com

${ }^{1}$ Plant Ecology Laboratory, Botany Department, Jai Narain Vyas University, Jodhpur, India

${ }^{2}$ Present Address: ICAR-Central Arid Zone Research Institute, Jodhpur, India
}

Among these, some of them are designated as degradation indicators while climatic and livestock activities are regarded as governing factors (Jafari and Bakhshandehmehr 2013; Miao et al. 2015).

Across the globe, land status (quantitative quality of land which usually based on some biotic and abiotic factors) was assessed by several workers by using different combinations of above cited parameters (Mandal et al. 2010; Wen et al. 2010; Mahdavi et al. 2013; McGranahan et al. 2013; Qiu et al. 2013; Masoudi 2014; Vieira et al. 2015; and Xie et al. 2015). Such studies were conducted on various types of land-use like rangelands (lands with predominant grasses, grass-like plants, forbs or shrubs suitable for grazing or browsing), pasture (lands that are primarily used for the production of adapted, domesticated forage plants for livestock), and forestland extended from temperate to tropical 
arid regions (de Soyza et al. 2000; Liu et al. 2004; Zhang et al. 2005; Masoudi et al. 2006; Li et al. 2009; Casson et al. 2009; Mandal et al. 2010; Wen et al. 2013; Qiu et al. 2013; Masoudi and Amiri 2015; Andrade et al. 2015).

In addition to these efforts, some assessment methodologies have also been developed like Status of Vegetation Condition (Kumar 1992), Habitat Complexity Score (Catling and Burt 1995), Pasture Condition Score (Cosgrove et al. 2001), Descriptor Sheet for USA Rangelands (Pyke et al. 2002) Habitat Hectares - Victoria (Parkes et al. 2003), Biodiversity Benefits Index (Oliver and Parkes 2003), Rapid Appraisal of Riparian Condition (Jansen et al. 2004), BioMetric (Gibbons et al. 2005), and BioCondition Assessment Toolkit (Eyre et al. 2006). In these studies and methodologies, physical (soil, hydrological) and biological (anthropogenic, livestock activities, and plant community characterization) parameters were estimated by a solitary land visit.

Further, studies from arid regions revealed that most of them are qualitative in nature (indicator assessment like good, moderate, severe, and very severe) and generally overlooked the significance of temporal fluctuation. In an arid region, temporal variations are very important for assessing the land qualities as it brings drastic changes in physical and biological properties of land between pulse (high resource availability), inter-pulse (small and irregular episode of resources: winter), and non-pulse events (Mathur and Sundaramoorthy 2016). Precipitation patterns significantly influence the structure and functions of arid and semi-arid ecosystems. In such areas, water availability works as "pulse," and in Indian arid region context, this denotes the rainy seasons, while inter-pulse period represents small and erratic episode of rains particularly occurred during winter season while the long dry period is referred as non-pulse period (summer). Such pulse/inter-pulse/non-pulse periods bring dramatic changes in soil moisture and associated biotic and abiotic components. Such yearly periodicity has the potential to affect the intra-annual population dynamics, species inter- and intra-specific interactions, and physiological and ecosystem processes and has been worked out at species-specific levels by many workers (Padilla et al. 2015). However, these were not explored with reference to land assessment studies.

Many hypotheses have been exercised for land degradation assessment and their associated parameters like agricultural intensification, inappropriate land management, and integration of local and scientific knowledge (D'Odorico and Ravi 2016). However, holistic assessment related to temporal changes in bio-physical indicators and ecosystem values still not work out. By analyzing these land appraisal attributes, two gaps have been identified with respect to the Indian arid region: (a) holistic studies were not conducted for land status assessment and (b) comportments of land qualities with different pulse events were also not correlated.

This study therefore sought to understand the temporal status of the Indian arid lands by using a new integrated approach having weighted qualitative and quantitative attributes of bio-physical and ecosystem value. This aim oscillated around two hypotheses; within the Indian arid region, a combined mathematical approach may assess the land qualities more precisely than individual use of status attribute, and temporal assessments are more informative compared to a single time assessment. Such cumulative and sequential assessments would enable us to better visualize our land health priorities for them.

\section{Methods}

\section{Land descriptions}

The study was conducted at 12 non-protected lands of the Indian arid region. These lands were selected by considering their geomorphologic characteristics, anthropogenic and grazing pressure, and species diversity dynamics and their temporal fluctuations. The samplings were carried out during three different seasons, i.e., rainy (July), winter (January), and summer (May), and data for different parameters were collected between the 15th and 25th of every respective month. Within each land, sampling zone was selected based on their continuity that is avoid any fragmentation, i.e., pathway, pits, waterbed, drainage channel mud, vegetative barrier, and zone that represent the fair amount of plant species diversity. Geographical coordinates and habitat types of each land are presented in Table 1 (the map of the study is provided in Additional file 1). From geo-morphological points of view, six lands were located at older alluvial plain, three and two were pertained to younger alluvial and hummock undulating terrains, respectively, and one was located on piedmonts area.

\section{Relative coverage score}

Relative coverage score (RCS) was quantified by community diversity parameters and modified bare patch index.

$$
\mathrm{RCS}=\frac{\text { Relative community diversity }}{\text { Bare patch index }}
$$

Relative community diversity (RCD) was quantified by using three quantitative attributes like species richness (SR), Shannon and Weaver diversity index (SDI), and evenness (E5) by following Ludwig and Reynolds (1999) and two qualitative parameters, i.e., litter conditions 
Table 1 GPS locations, habitat types, and other attributes of sampling lands at Jodhpur

\begin{tabular}{|c|c|c|c|c|c|c|c|}
\hline \multirow{2}{*}{$\begin{array}{l}\text { Land } \\
\text { no. }\end{array}$} & \multicolumn{2}{|l|}{ Coordinates } & \multirow{2}{*}{$\begin{array}{l}\text { Habitat } \\
\text { types }\end{array}$} & \multicolumn{4}{|c|}{ Soil textures (\%) } \\
\hline & $\mathrm{N}$ & $E$ & & Clay & Silt & Sand & Gravel \\
\hline 1 & $26^{\circ} 12^{\prime} 29.5^{\prime \prime}$ & $73^{\circ} 04^{\prime} 24.8^{\prime \prime}$ & HUT & 28.5 & 4.3 & 66.0 & 1.1 \\
\hline 2 & $26^{\circ} 15^{\prime} 1.8^{\prime \prime}$ & $73^{\circ} 59^{\prime} 29.8^{\prime \prime}$ & OAP & 29.6 & 1.3 & 68.7 & 0.2 \\
\hline 3 & $26^{\circ} 12^{\prime} 48.4^{\prime \prime}$ & $73^{\circ} 4^{\prime} 7.8^{\prime \prime}$ & OAP & 26.3 & 17.8 & 35.5 & 20.1 \\
\hline 4 & $26^{\circ} 11^{\prime} 33.4^{\prime \prime}$ & $73^{\circ} 3^{\prime} 6.1^{\prime \prime}$ & YAP & 17.0 & 25.4 & 23.5 & 33.5 \\
\hline 5 & $26^{\circ} 14^{\prime} 47.01^{\prime \prime}$ & $73^{\circ} 0.0^{\prime} 58.9^{\prime \prime}$ & OAP & 28.7 & 21.3 & 31.2 & 18.8 \\
\hline 6 & $26^{\circ} 14^{\prime} 12.4^{\prime \prime}$ & $73^{\circ} 01^{\prime} 24.2^{\prime \prime}$ & OAP & 29.1 & 18.5 & 43.3 & 10.2 \\
\hline 7 & $26^{\circ} 21^{\prime} 54.5^{\prime \prime}$ & $73^{\circ} 03^{\prime} 48.9^{\prime \prime}$ & YAP & 25.3 & 15.4 & 37.4 & 21.4 \\
\hline 8 & $26^{\circ} 12^{\prime} 33.7^{\prime \prime}$ & $73^{\circ} 4^{\prime} 8.4^{\prime \prime}$ & OAP & 27.6 & 26.8 & 30.3 & 14.8 \\
\hline 9 & $26^{\circ} 14^{\prime} 31.6^{\prime \prime}$ & $73^{\circ} 01^{\prime} 21.1^{\prime \prime}$ & OAP & 33.3 & 17.8 & 42.7 & 4.9 \\
\hline 10 & $26^{\circ} 18^{\prime} 47.0^{\prime \prime}$ & $72^{\circ} 60^{\prime} 35.1 "$ & PA & 29.5 & 4.2 & 43.0 & 23.2 \\
\hline 11 & $26^{\circ} 17^{\prime} 2.5^{\prime \prime}$ & $72^{\circ} 56^{\prime} 5.9^{\prime \prime}$ & YAP & 27.7 & 3.6 & 61.5 & 7.0 \\
\hline 12 & $26^{\circ} 20^{\prime} 58.9^{\prime \prime}$ & $73^{\circ} 3^{\prime} 57.2^{\prime \prime}$ & HUT & 30.1 & 10.6 & 56.4 & 2.7 \\
\hline
\end{tabular}

HUT hummock undulating terrains, OAP old alluvium plains, YAP younger alluvium plain, PA piedmonts area

(LC) and removal of plant parts (RPP), as described by Kumar (1992) and depicted in Table 2. Scaling number of each qualitative attribute was assigned after complete physical survey of each land during sampling periods, and this approach was adopted to enhance the judging efficiency for qualitative parameters. At each land and during each event, nested quadrate technique was utilized wherein 10 quadrates of $10 \times 10 \mathrm{~m}$ abutting each other in a row were laid across the field (Kent and Coker 1992) applied for woody perennial, and within each quadrate, $1 \times 1$ $\mathrm{m}$ area was applied for herbaceous biomass (Saxena and Aggarwal 1983; Narita and Wada 1998). Relative importance value was calculated through relative frequency, abundance, and density (Kent and Coker 1992). Diversity indices were calculated as per standard methodology (Ludwig and Reynolds 1999). The species richness is defined as the total number of species per sampling unit (Bhattarai et al. 2004). Shannon-Weaver is a diversity index and generally ranges from 1.5 to 3.5 and rarely up to 4.5. Its higher value indicates the high diversity while the lower value represents the dominance of few species.
In RCD index, weights were determined by the percent of variation in the data set explained by the principal component analysis that contributed the indicated variable divided by the total percentage of variation explained by all the $\mathrm{PCs}$ with eigenvectors more than one (Andrews et al. 2002), and thus, mathematically, $\mathrm{RCD}$ is express as:

$$
\begin{aligned}
\mathrm{RCD}= & \sum\left(\frac{(\mathrm{SR} \times 0.336)+(\mathrm{SDI} \times 0.331)+(\mathrm{E} 5 \times 0.394)}{3}\right) \\
& \times\left(\frac{(\mathrm{LC} \times 0.281)+(\mathrm{RPP} \times 0.234)}{2}\right)
\end{aligned}
$$

The second attribute of RCS, i.e., bare patch index $\mathrm{x}_{\text {Modi- }}$ fied, was quantified by using the mean size of bare patches at land $\left(B_{\text {Mean }}\right)$ and is the total bare soil $(\Sigma \mathrm{B})$ and total transect length $(\Sigma \mathrm{L} 100 \mathrm{~m})$. This mathematical expression has a multiplication factor of connectivity of bare patch where 1 was used for inter-connected bare

\begin{tabular}{|c|c|c|c|c|c|}
\hline \multirow[t]{2}{*}{ Parameter } & \multicolumn{5}{|l|}{ Ratings } \\
\hline & $1^{\mathrm{a}}$ & $2^{\mathrm{a}}$ & $3^{\mathrm{a}}$ & $4^{a}$ & $5^{a}$ \\
\hline Removal of plant parts (\%) & Up to 50 & $51-75$ & $76-85$ & $86-95$ & $>95$ \\
\hline Litter condition & Accumulating & Replacing & None & - & - \\
\hline Bot. Sp. composition of climax vegetation (BSC\%) & $25-40$ & 10 to $<25$ & $1-<10$ & $<1$ & - \\
\hline Relative importance value (RIV) of climax species & Over 25 & 10 to $<25$ & 6 to $<10$ & 1 to $<6$ & $<1$ \\
\hline Carrying capacity (ACU/100 ha) & 20 & 17 & 13 & 5 & None \\
\hline Grazing intensity (Gl) & Light & Moderate & Heavy & Very heavy & - \\
\hline Density of un-palatable species (DUP) & $10-20$ & $21-40$ & $41-60$ & $61-80$ & $>80$ \\
\hline
\end{tabular}

Table 2 Rating parameters of various qualitative attributes applied for land status at Jodhpur

${ }^{a} 1,2,3,4$, and 5 represent good quality, slight, moderate, severe and very severe degradation, respectively 
patches and 0.5 for their non-connectivity. Thus, this equation can be equated as:

$$
\begin{aligned}
& \mathrm{BPI}_{\text {Modif }=} B_{\text {Mean }} \times\left(\frac{\sum B}{\sum L}\right) \\
& \times \text { Connectivity of bare patch }\{\text { i.e., } 1 \text { for yes and } 0.5 \text { for no }\}
\end{aligned}
$$

\section{Herbaceous component score}

Ecological information on herbaceous component were collected within $1 \mathrm{~m}^{2}$ plot at each $10 \times 10 \mathrm{~m}$ quadrate, and their standing biomass was calculated by harvesting them at $0.5 \mathrm{~cm}$ above ground level. Constant weight was obtained after 10 days of clipping (Bhattarai et al. 2004).

Obtained biomass (THB $=$ total herbaceous biomass) was converted into scale criteria (up to $50 \mathrm{~g}^{2}$ scale one; 51-100 $\mathrm{g}^{2}$ scale two; $101-150 \mathrm{~g}^{2}$ scale three; $151-200$ and 201-300 $\mathrm{g}^{2}$ were scales for four and five, respectively). Other components of HCS involve botanical species composition of climax vegetation (BSC), relative importance value of climax species (RIV of C. spp.), carrying capacity (C. Cap ACU/100 ha), grazing intensity (GI), and density of un-palatable species (DUP), and these were calculated by scoring criteria as depicted in Table 2 .

The percent of potential or climax species below a certain level in the entire composition of herbaceous layer indicates the status of degradation. With refrence to botanical species composition of climax vegetation, good, slight, moderate, severe, and very severe degradations are indicated by 25 to 40,10 to $<25,1$ to $<10,<1$, and absent, respectively. In normal, un-degraded situations, the climax species have high dominance, expressed as relative importance value (RIV) followed by those of successional species. Based on the pattern of dominance, five assessment stages can be framed (Table 2). The concept of carrying capacity was employed for a community with good health and at sustained biomass production. Carrying capacity is the number of animals that can graze a piece of land on a year-round basis. In the present study, five-stage rating was utilized (Table 2). These attributes with their weighted factor are expressed as:

$$
\begin{aligned}
\mathrm{HCS} & =\left(\frac{(\mathrm{THB} \times 0.334)+(\mathrm{BSC} \times 0.409)+(\mathrm{RIV} \text { of C spp. } \times 0.392)}{3}\right) \\
& \times\left(\frac{(\mathrm{C} \mathrm{Cap} . \times 0.276)+(\mathrm{GI} \times 0.234)}{\mathrm{DUP} \times 0.532}\right)
\end{aligned}
$$

\section{Soil quality index}

Soil samples were collected up to $30 \mathrm{~cm}$ depth at all lands during the seasons. All the soil parameters were quantified in triplicate. Soil moisture (\%) was estimated in non-dried soil through gravimetric method (Black 1965), while other physical and chemical parameters were estimated in well air-dried and sieved $(2 \mathrm{~mm})$ soil samples (Pandeya et al. 1968). Electrical conductivity $(\mathrm{mS} / \mathrm{m})$ and soil $\mathrm{pH}$ were measured in water-soil suspension $(5: 1)$ by respective digital meters. Soil organic carbon, total nitrogen, and available phosphorus (mg/100 g) were quantified by standard methodologies of Jackson (1973) and Allen et al. (1976). Again, weighting factors were determined through PCA analysis.

$$
\mathrm{SQI}=\left(\begin{array}{l}
\left(S_{\mathrm{OC}} \times 0.274\right)+\left(S_{\mathrm{P}} \times 0.321\right)+\left(S_{\mathrm{N}} \times 0.467\right) \\
\frac{+\left(S_{\mathrm{pH}} \times 0.267\right)+\left(S_{\mathrm{EC}} \times 0.215+\left(S_{\mathrm{M}} \times 0.299\right.\right.}{\text { Number of studied parameters }}
\end{array}\right)
$$

where $S_{\mathrm{OC}}=$ soil organic carbon, $S_{\mathrm{P}}=$ soil available phosphorus, $S_{\mathrm{N}}=$ soil nitrogen, $S_{\mathrm{pH}}=$ soil $\mathrm{pH}, S_{\mathrm{EC}}=$ soil electrical conductivity, and $S_{\mathrm{M}}=$ soil moisture. Revised SQI was quantified by the following formula:

$$
\mathrm{SQI}_{\text {Revised }}=\frac{\sum \mathrm{SQUI}-\mathrm{SQI}_{\text {Minimum }}}{\mathrm{SQI}_{\text {Maximum }}-\mathrm{SQI}_{\text {Minimum }}}
$$

\section{Ecosystem monitoring value (soil)}

EMV $_{\text {Soil }}$ was determined by quantification of value of ecosystem carbon and nitrogen sequestration as described by Wen et al. (2013):

$$
\mathrm{EMV}_{\text {Soil }}=V_{\mathrm{C}}+V_{\mathrm{N}}
$$

where $V_{\mathrm{C}}$ is the value of ecosystem carbon sequestration.

$$
V_{C}=\sum P_{C} \times \mathrm{OC}_{\text {up to } 30 \mathrm{~cm}}
$$

where $P_{\mathrm{C}}$ is the price of carbon tax (50 in India, Stern 2013) and $\mathrm{OC}_{\mathrm{up}}$ to $30 \mathrm{~cm}$ is the soil organic carbon up to $30 \mathrm{~cm}$ soil depth. $V_{\mathrm{n}}$ is the value of ecosystem nitrogen sequestration.

$$
V_{N}=\frac{\sum P_{N}}{46 \%} \times \mathrm{TN}_{\text {up to }} 30 \mathrm{~cm} \times 0.081
$$

Here, opportunity cost was applied to assess the nitrogen sequestration (in India, average price of urea fertilizer is about $10 / t \mathrm{P}_{\mathrm{N}}$ ). $\mathrm{TN}_{\mathrm{up}}$ to $30 \mathrm{~cm}$ is the soil nitrogen up to $30 \mathrm{~cm}$ soil depth, $46 \%$ is the percentage of total $\mathrm{N}$ in urea (Lin et al. 2007), and 0.081 is the proportion of content of available nitrogen in total nitrogen.

\section{Status of land}

Thus, overall land status was assessed by following mathematical expression. 


$$
\text { Status of land }=\sum_{+\mathrm{EMV}_{\text {Soil }}} \mathrm{RCS}+\mathrm{HCS}+\mathrm{SQI}_{\text {Revised }}
$$

Score of this index ranges from 1.0 to 2.5 , and value ranges from 1.0 to $1.3,>1.3$ to $<1.6,>1.6$ to $<2.1$, and $>2.1$ to 2.5 represent lower, moderate, high, and very high value status of land, respectively.

\section{Statistical analysis}

Distribution behaviors of qualitative parameters (removal of plant parts, litter condition, botanical species composition of climax species, RIV of climax species, carrying capacity, and density of un-palatable species) and scoring efficiency of the researcher were accessed by frequency distribution. Results of this non-parametric test were interpreted through skewness, kurtosis, and Kolmogorov-Smirnov tests.

Principal component analysis (PCA) is an Eigen value-based ordination method, and this was performed with Pearson correlation coefficient (Xlstat software, 2007). This multi-variant technique was utilized for two objectives, i.e., (a) to find out weighting factor for various attributes with the help of variables like richness, Shannon and Weaver index, evenness, total herbage biomass, botanical species composition of climax species, RIV of climax species, carrying capacity, grazing intensity, density of unpalatable species, removal of plant parts, litter conditions, soil organic carbon, phosphorus, nitrogen concentrations, $\mathrm{pH}$, electrical conductivity, and moisture content and (b) to characterize the temporal variation of land assessment parameters that includes RCS, revised SQI, HCS, and EMV. For the second objective, variables and their significant relationships were identified through the concept of component defining variables (CDV) which works through correlation coefficient (Iwara et al. 2011). Student $t$ test was applied to assess the significance of temporal factor for various quantified parameters (community and soil) and for calculated index (RCS, HCS, revised SQI, EMV, and for land status).

\section{Results}

During the study period, maximum $\left(39.08^{\circ} \mathrm{C}\right)$ and minimum $\left(13.1^{\circ} \mathrm{C}\right)$ temperature was recorded during non-pulse and inter-pulse events, respectively. Such trends for relative humidity (maximum $72.37 \%$ and minimum 18\%) were recorded during pulse and non-pulse events, respectively. High rainfall $(61.28 \mathrm{~mm})$ was recorded during pulse, followed by non-pulse $(12.55 \mathrm{~mm})$ and inter-pulse $(0.12 \mathrm{~mm})$. Cenchrus biflorus Roxb., Aristida funiculata Trin. and Rupr., Lasiurus sindicus Henr., Dactyloctenium aegyptium L. (Willd.), and Eragrostis ciliaris L. (Wolf.) were major herbaceous components, while Tephrosia purpurea L. (Pers.), Cassia angustifolia M. (Vahl.), Lepidagathis cristata (Willd), and Corchorus depressus (Linn.) were major woody perennials. Details of various soil, vegetation, and other indices are presented in Table 3. Highest species richness and diversity (Shannon and Weaver) were recorded during pulse followed by inter-pulse and non-pulse events. Evenness suggested the distribution of the individual species within community, and it fluctuates with shifting of proportional abundance of the species (Ludwig and Reynolds 1999). A slight higher evenness was recorded during inter-pulse compared to pulse.

Table 3 Range of various communities, soil, and various assessment indices

\begin{tabular}{llll}
\hline Parameters & Pulse & Inter-pulse & Non-pulse \\
\hline Bare patch & $2.4-23.61(5.93)$ & $4.59-29.23(16.54)$ & $3.65-37.31(21.70)$ \\
Species richness & $7-12(9.08)$ & $4-8(5.92)$ & $2-7(3.83)$ \\
Shannon diversity & $1.73-2.38(2.02)$ & $1.3-2.0(1.68)$ & $0.54-1.71(1.14)$ \\
Evenness & $0.56-1.71(0.93)$ & $0.81-1.9(0.95)$ & $0.86-1.04(0.89)$ \\
Soil organic carbon & $19.16-187.89(54.1)$ & $62.86-384(166.42)$ & $19.54-432(153.50)$ \\
Soil phosphorus & $21.38-54.06(37.05)$ & $10.36-44.8(24.45)$ & $4.74-25.30(11.44)$ \\
Soil nitrogen & $19.16-76.25(40.28)$ & $18.95-112.65(76.85)$ & $16.85-255(90.95)$ \\
Soil pH & $6.58-9.11(8.56)$ & $6.23-7.97(7.53)$ & $6.3-8.15(7.77)$ \\
Soil EC (mSm) & $0.13-0.54(0.26)$ & $0.14-0.28(0.23)$ & $0.10-0.29(0.16)$ \\
Soil moisture (\%) & $3.81-12.42(7.17)$ & $0.93-4.53(1.80)$ & $0.36-1.86(0.86)$ \\
Relative coverage score & $0.02-0.36(0.16)$ & $0.013-0.15(0.05)$ & $0.005-0.14(0.04)$ \\
Revised SQl & $0.003 .389(0.15)$ & $0.307-0.78(0.46)$ & $0.07-1.0(0.45)$ \\
Herbaceous component score & $0.90-1.79(1.31)$ & $0.78-1.41(1.03)$ & $0.653-1.413(0.97)$ \\
EMV & $0.015-0.100(0.03)$ & $0.046-0.199(0.10)$ & $0.021-0.232(0.09)$ \\
Land status & $1.23-2.15(1.65)$ & $1.26-2.09(1.63)$ & $1.0-2.37(1.56)$ \\
\hline
\end{tabular}

Bare patch ( $\mathrm{m}$ in $100 \mathrm{~m}$ line transect). Soil organic carbon, nitrogen, and phosphorus are in $\mathrm{mg} / 100 \mathrm{~g}$. Readings in parentheses are the average of respective parameter 
Ranges of various quantitative parameters are presented in Table 3. Bare patch (meter in $100 \mathrm{~m}$ line transect), soil organic carbon, nitrogen, SQI, and land status increased from pulse to non-pulse events. RCS and HCS were recorded minimum $(0.005,0.65)$ during non-pulse event and maximum $(0.36,1.79)$ during pulse event, respectively. Furthermore, with our integrated approach, $7,14,12$, and 3 were assessed as lower, moderate, high, and very high quality land, respectively. The seasonal variability in soil $\mathrm{pH}$ could be attributed to temperature and movement of cations like calcium, magnesium, and potassium. This can further linked with soil organic carbon content that acted to reverse with soil pH (maximum and minimum of both these were recorded during inter-pulse, respectively). Such relationships have been explored by many workers under decomposition process (Salim et al. 2015). High soil nitrogen content during the pulse event can be explained by the fact that this soil attribute followed first-order kinetics and that represents the effect of temperature on it with the rate of doubling of each of $10{ }^{\circ} \mathrm{C}$ increase in temperature. Such information also revealed the temperature dependent decompositions of celluloses and proteases soil enzymes that reflected in seasonal variations in soil organic matter and nitrogen contents (Guntinas et al. 2012).
Results of frequency distribution (FD) parameters (skewness, kurtosis, Kolmogorov-Smirnov tests) are depicted in Table 4. For a normal distribution, kurtosis value is exactly 3 and termed as mesokurtic, $<3$ called platykurtic (its central peak is lower and broader), and $>3$ called leptokurtic (central peak is higher and sharper). In the present study, litter condition during non-pulse and botanical composition of climax species during pulse event were mesokurtic, while other visual parameters during different events were platykurtic. Higher computed $p$ value of K-S test compared to significance level (alpha $=0.05)$ suggested the normal distribution of qualitative parameters except for litter condition (LC) during pulse and inter-pulse events (Table 4). Normal distributions for carrying capacity and for grazing intensity were also showed by skewness as their value equals to zero. High positive skewness is recorded for RIV of climax species during pulse and inter-pulse events and botanical compositions of climax species during non-pulse event. Figures are provided in Additional file 1.

Interpretation and identification of the significant variables on PCA bi-plot were carried out by the criterion provided by Legendre and Legendre (1998) and Iwara et al. (2011). In this study, the cumulative percentage in PCA

Table 4 Frequency parameters of different visual parameters

\begin{tabular}{|c|c|c|c|c|}
\hline Parameters & Events & Skewness (Pearson) & Kurtosis (Pearson) & Kolmogorov-Smirnov test (at alpha 0.05 level) \\
\hline \multirow[t]{3}{*}{ Removal of plant parts } & $P$ & 562 & -0.967 & 0.166 \\
\hline & IP & 0.816 & -0.681 & 0.075 \\
\hline & NP & -0.166 & -1.09 & 0.431 \\
\hline \multirow[t]{3}{*}{ Liter condition } & P & -1.57 & 0.529 & $0.003^{\mathrm{NS}}$ \\
\hline & $\mathbb{P}$ & -1.57 & 0.529 & $0.003^{\mathrm{NS}}$ \\
\hline & NP & 1.6 & 3.2 & 0.007 \\
\hline \multirow[t]{3}{*}{ Botanical species composition of climax } & $P$ & 1.6 & 3.2 & 0.007 \\
\hline & $\mathrm{IP}$ & 0.816 & -0.681 & 0.075 \\
\hline & NP & 1.324 & 1.147 & 0.281 \\
\hline \multirow[t]{3}{*}{ RIV of climax species } & $P$ & 1.25 & 1.21 & 0.091 \\
\hline & $\mathrm{IP}$ & 1.14 & 0.87 & 0.011 \\
\hline & NP & 0.817 & -0.313 & 0.172 \\
\hline \multirow[t]{3}{*}{ Carrying capacity (ACU/100 ha) } & $P$ & 0 & -2.16 & 0.11 \\
\hline & $\mathbb{P}$ & 0 & -0.521 & 0.06 \\
\hline & NP & -0.04 & -0.52 & 0.063 \\
\hline \multirow[t]{3}{*}{ Grazing intensity } & $P$ & 0 & -0.521 & 0.063 \\
\hline & IP & 0 & -1.3 & 0.387 \\
\hline & NP & -0.123 & -1.53 & 0.615 \\
\hline \multirow[t]{3}{*}{ Density of un-palatable species } & $P$ & -0.754 & -1.11 & 0.078 \\
\hline & $\mathbb{P}$ & -0.589 & -0.26 & 0.11 \\
\hline & NP & -0.277 & -0.708 & 0.558 \\
\hline
\end{tabular}


analysis conducted for gaining the weighting factors suggested that during all temporal events, the first four axes together accounted more than $80 \%$ variability (Table 5) and this proved the usefulness of this tool in this study (Wei-Giang and Bilquees 2008). Similarly, the first four axes of PCA analysis carried out to characterize the temporal variations of land assessment parameters (RCS, revised SQI, HCS, and EMV) suggested 100\% cumulative variability (Table 6), and usefulness of this tool was further proved by lack of any arch effect in PCA bi-plots (Figs 1 and 2). On each component, variable with loading $\geq 0.70$ was identified as the significant variable (Iwara et al. 2011; Mathur 2015).

Variables bi-plot during various events showed that during pulse event, soil organic carbon is located in opposite direction of community diversity (Shannon and Weaver index) and richness, while during inter-pulse and non-pulse events, they are located on the same axes. Furthermore, soil $\mathrm{pH}$ and litter condition during all the events were located on opposite sides to each other; however, axes distances between them continuously increased from pulse (non-significant) to inter-pulse $(-0.543)$ to non-pulse events $(-649)$. Soil nitrogen and phosphorus were located in opposite directions of community diversity (Shannon and Weaver index) and herbage biomass during all the events (Fig. 1).

Results revealed that all the quantified parameters were significant (Table 6) and four different trends were recognized with respect to locations of parameters at different axes: (a) during all the events parameter located on similar component, i.e., land status; (b) located on different components during different pulse events, i.e., $\mathrm{RCI}$; (c) during pulse event located on $\mathrm{F}_{2}$ component, while for the rest two events located at $F_{1}$, i.e., SQI and EMV; and (d) reverse of previous trends, i.e., HCS (Table 6). Further, PCA bi-plot for different lands, constructed with these indices during different events, also revealed the temporal changes in land qualities for example land 2 and 9 (Fig. 2).

The significance of various quantitative parameters (community and soil) and indices (RCS, SQI, HCS, EMV, and land status) between different events were assessed through Student $t$ test, and results are depicted in Table 7. This test revealed that among community parameters, evenness was recorded non-significant between all the events, and among soil parameters, SOC and nitrogen were recorded non-significant between inter-pulse to pulse events.

Table 5 Attributes of PCA pertains to various variables

\begin{tabular}{|c|c|c|c|c|c|c|c|c|c|c|c|c|}
\hline \multirow[t]{2}{*}{ Events } & \multicolumn{4}{|l|}{ Pulse } & \multicolumn{4}{|c|}{ Inter-pulse } & \multicolumn{4}{|c|}{ Non-pulse } \\
\hline & F1 & F2 & F3 & F4 & $\overline{F 1}$ & $\mathrm{~F} 2$ & F3 & $\mathrm{F} 4$ & $\overline{F 1}$ & $\mathrm{~F} 2$ & F3 & F4 \\
\hline Eigen value & 4.34 & 3.17 & 2.52 & 1.97 & 5.527 & 3.016 & 2.192 & 1.684 & 5.465 & 3.115 & 2.699 & 1.755 \\
\hline Variability (\%) & 35.44 & 22.69 & 14.86 & 11.61 & 39.51 & 25.74 & 12.89 & 9.90 & 36.77 & 24.27 & 15.87 & 10.32 \\
\hline Cumulative \% & 35.44 & 58.13 & 73.00 & 84.62 & 39.51 & 65.25 & 78.14 & 88.05 & 36.77 & 61.04 & 76.91 & 87.24 \\
\hline Richness & $0.751^{\mathrm{a}}$ & -0.376 & -0.058 & -0.398 & $0.776^{\mathrm{a}}$ & 0.343 & -0.292 & -0.229 & -0.402 & $0.832^{\mathrm{a}}$ & -0.003 & -0.255 \\
\hline Shannon and Weaver index & $0.813^{\mathrm{a}}$ & -0.428 & 0.062 & -0.296 & $0.888^{\mathrm{a}}$ & 0.330 & -0.073 & -0.202 & -0.402 & $0.743^{\mathrm{a}}$ & 0.067 & -0.284 \\
\hline Evenness & 0.582 & 0.020 & 0.661 & 0.025 & 0.307 & -0.040 & 0.689 & -0.392 & 0.332 & -0.670 & 0.047 & -0.331 \\
\hline Organic carbon & -0.109 & 0.608 & -0.209 & -0.461 & 0.294 & 0.588 & 0.008 & 0.399 & -0.165 & 0.509 & -0.326 & 0.643 \\
\hline Soil P & -0.567 & -0.224 & 0.558 & 0.050 & -0.580 & 0.199 & 0.437 & -0.222 & $0.810^{\mathrm{a}}$ & -0.001 & 0.527 & 0.123 \\
\hline Soil nitrogen & $-0.749^{\mathrm{a}}$ & 0.130 & 0.411 & -0.261 & 0.048 & -0.641 & 0.481 & 0.026 & 0.161 & -0.232 & 0.534 & 0.309 \\
\hline Soil pH & 0.547 & 0.019 & -0.422 & 0.375 & 0.569 & 0.385 & 0.363 & 0.535 & -0.680 & 0.066 & 0.337 & -0.004 \\
\hline Electric conductivity & 0.089 & -0.475 & -0.064 & 0.566 & 0.388 & 0.575 & 0.212 & 0.145 & 0.022 & -0.041 & $0.878^{\mathrm{a}}$ & -0.172 \\
\hline Soil moisture & 0.418 & 0.680 & 0.387 & -0.144 & 0.534 & -0.048 & 0.461 & -0.250 & -0.002 & 0.396 & $0.775^{\mathrm{a}}$ & 0.007 \\
\hline Removal of plant parts & 0.230 & 0.565 & -0.168 & 0.053 & -0.467 & $0.708^{\mathrm{a}}$ & -0.332 & -0.080 & 0.683 & 0.316 & -0.146 & -0.526 \\
\hline Litter condition & -0.241 & -0.158 & 0.361 & $0.786^{a}$ & -0.422 & 0.203 & 0.552 & 0.569 & $0.846^{\mathrm{a}}$ & 0.038 & -0.411 & 0.120 \\
\hline Total herbage biomass $\mathrm{gm}^{-2}$ & 0.144 & $-0.742^{a}$ & -0.119 & -0.376 & 0.665 & 0.380 & -0.086 & -0.481 & -0.415 & 0.345 & 0.005 & -0.550 \\
\hline $\begin{array}{l}\text { Botanical species composition } \\
\text { of climax vegetation }\end{array}$ & 0.667 & 0.267 & 0.558 & -0.025 & -0.757 & 0.494 & 0.087 & -0.249 & $0.883^{\mathrm{a}}$ & 0.322 & -0.186 & -0.090 \\
\hline $\begin{array}{l}\text { Relative importance value (RIV) } \\
\text { of climax species }\end{array}$ & $0.764^{\mathrm{a}}$ & -0.182 & 0.430 & 0.230 & -0.696 & -0.143 & 0.126 & -0.400 & $0.723^{\mathrm{a}}$ & 0.349 & 0.115 & 0.101 \\
\hline Carrying capacity (ACU/100 ha) & 0.321 & $0.837^{\mathrm{a}}$ & -0.105 & 0.302 & $-0.861^{\mathrm{a}}$ & 0.270 & -0.337 & 0.076 & $0.788^{\mathrm{a}}$ & 0.095 & -0.216 & -0.359 \\
\hline Grazing intensity & -0.368 & -0.096 & 0.647 & -0.238 & -0.407 & 0.531 & 0.351 & -0.237 & 0.687 & 0.116 & 0.502 & 0.028 \\
\hline Density of un-palatable species & -0.007 & 0.134 & 0.359 & -0.020 & -0.233 & 0.450 & 0.364 & -0.114 & 0.331 & 0.692 & 0.035 & 0.452 \\
\hline
\end{tabular}

a Variable with loading $\geq 0.70$ were identified as significant variable and marked in italics 


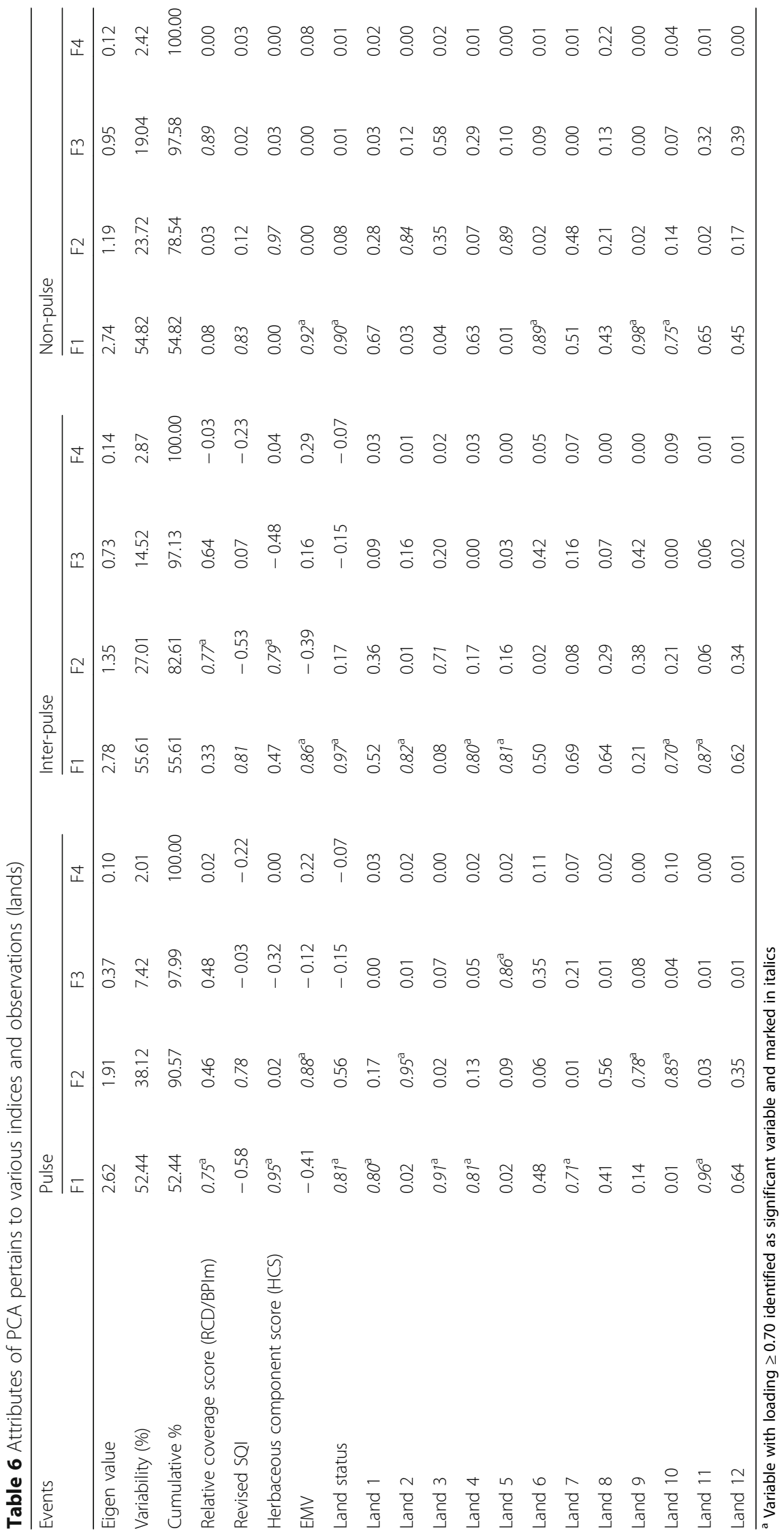




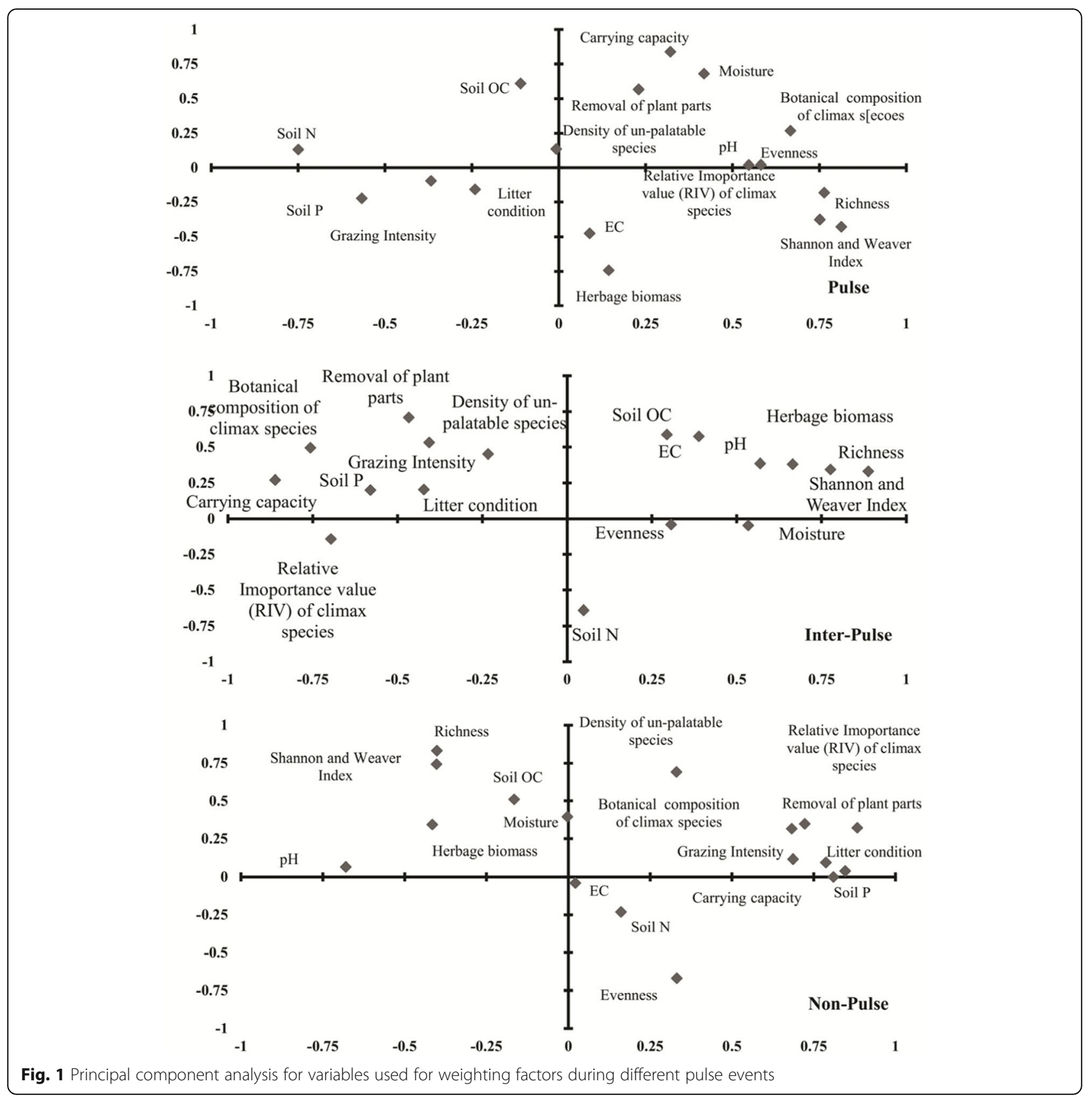

In the present study, regression analysis showed power relationships of bare patch index with species richness $\quad$ (species richness $=13.668 \times$ bare patch index $\left.{ }_{\text {mod }}{ }^{\wedge}{ }^{-0.3532} R^{2}=0.732, \quad P<0.01 \pm 1.81\right), \quad$ while linear positive relationships were recorded between $\mathrm{HCS}$ and RCD (HCS $=0.73+0.74 \times \mathrm{RCD}, R^{2}=0.458$, $P<0.01 \pm 0.247)$ and negative linear relationship between HCS and revised SQI $(\mathrm{HCS}=1.27+-0.488 \times$ revised SQI $R^{2}=0.470 \quad P<0.01 \pm 0.245$ ); however, RCS and revised SQI do not show any significant relationship.

\section{Discussion}

\section{Statistical behavior}

In the present study, three parameters, viz, vegetation, soil, and ecosystem value, were temporally assessed for evaluating the quality of the Indian arid land. Some of the parameters were inherent quantitative in nature while some were qualitative, and both types of variables were homogenized by applying weighting factor. Further, scoring efficiency of qualitative parameters varies with researcher experience, and in the present study, such field-based experience was judged by frequency distribution. 


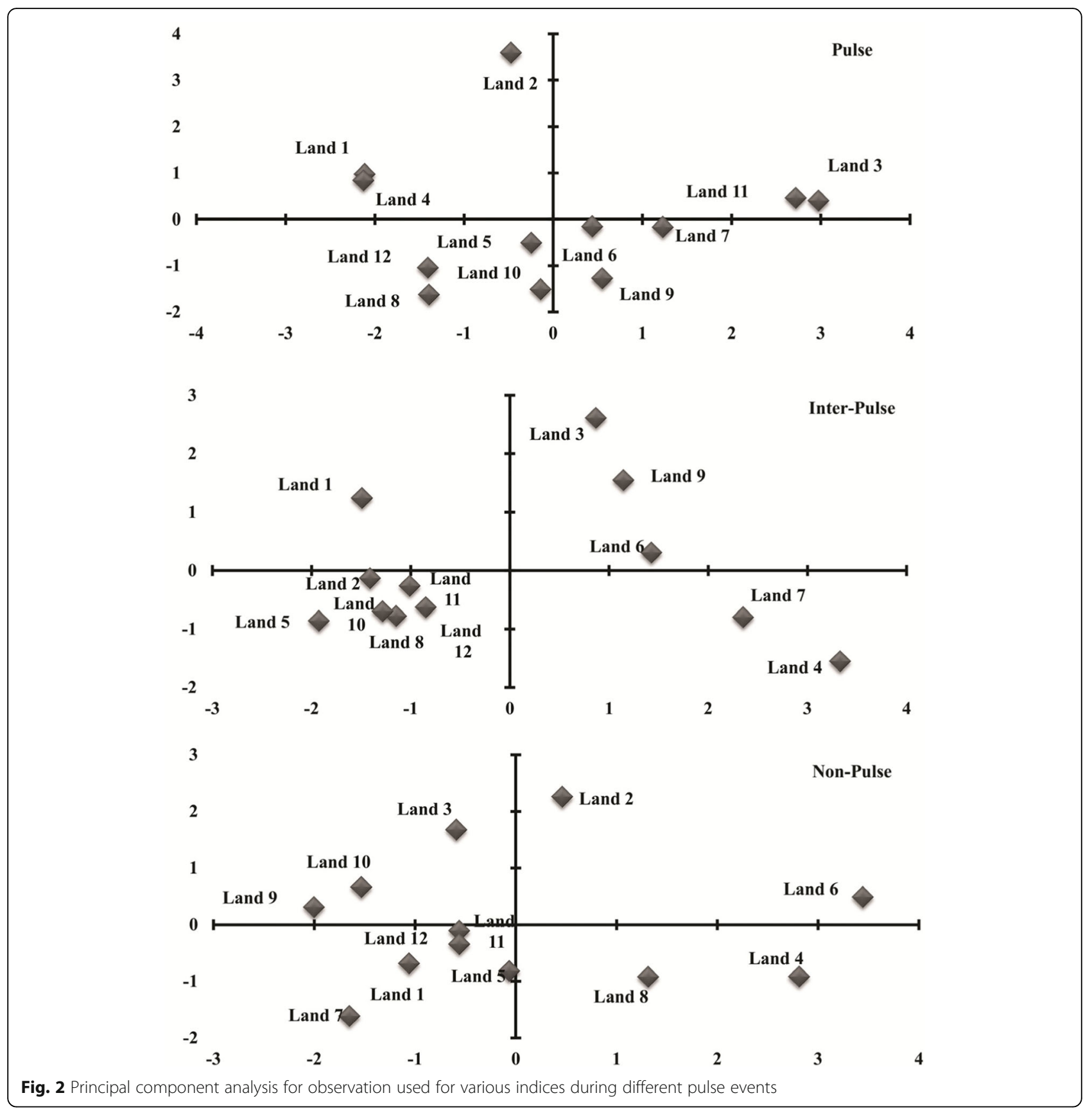

Results of this non-parametric method showed normal distribution (by kurtosis and K-S tests) for most of the parameters; however, positive skewness for RIV of climax species was recorded which can be explained by the addition of other species during pulse and inter-pulse events. Thus, in the present study, qualitative parameters utilized to develop a quantitative approach for appraisal of Indian arid lands were efficiently assessed that eventually supported the efficiency of proposed techniques.
Student $t$ test was conducted to appraise the variabilities in quantitative parameters (community and soil) and in calculated indices (RCS, SQI, HCS, EMV, and for land status). For evenness, non-significant $t$ test value between various events suggested the distribution level of the individual at a similar intensity. Thus, it indirectly indicated the homogenous land selected for this study (Gotelli and Chao 2013). A statistically significant $t$ test between pulse to inter-pulse and pulse to non-pulse for different calculated indices and non-significant between 
Table 7 Results of Student $t$ test for various parameters

\begin{tabular}{|c|c|c|c|}
\hline Parameters & Events & Inter-pulse & Non-pulse \\
\hline \multirow[t]{2}{*}{ Bare patch } & Pulse & $3.42^{\mathrm{b}}$ & $4.61^{b}$ \\
\hline & Inter-pulse & - & $1.91^{\mathrm{a}}$ \\
\hline \multirow[t]{2}{*}{ Species richness } & Pulse & $6.43^{b}$ & $12.87^{\mathrm{b}}$ \\
\hline & Inter-pulse & - & $5.00^{\mathrm{b}}$ \\
\hline \multirow[t]{2}{*}{ Shannon diversity index } & Pulse & $6.21^{\mathrm{b}}$ & $9.81^{\mathrm{b}}$ \\
\hline & Inter-pulse & - & $6.01^{\mathrm{b}}$ \\
\hline \multirow[t]{2}{*}{ Evenness } & Pulse & $0.45^{\mathrm{NS}}$ & $1.06^{\mathrm{NS}}$ \\
\hline & Inter-pulse & - & $1.66^{\mathrm{NS}}$ \\
\hline \multirow[t]{2}{*}{ Soil organic carbon } & Pulse & $3.99^{\mathrm{b}}$ & $2.83^{\mathrm{b}}$ \\
\hline & Inter-pulse & - & $0.372^{\text {NS }}$ \\
\hline \multirow[t]{2}{*}{ Soil phosphorus } & Pulse & $3.56^{\mathrm{b}}$ & $7.26^{\mathrm{b}}$ \\
\hline & Inter-pulse & - & $4.14^{\mathrm{b}}$ \\
\hline \multirow[t]{2}{*}{ Soil nitrogen } & Pulse & $3.71^{\mathrm{b}}$ & $2.78^{b}$ \\
\hline & Inter-pulse & - & 0.89 NS \\
\hline \multirow[t]{2}{*}{ Soil pH } & Pulse & $7.56^{\mathrm{b}}$ & $9.24^{\mathrm{b}}$ \\
\hline & Inter-pulse & - & $2.01^{\mathrm{a}}$ \\
\hline \multirow[t]{2}{*}{ Soil electric conductivity } & Pulse & $0.96^{\mathrm{NS}}$ & $2.47^{\mathrm{b}}$ \\
\hline & Inter-pulse & - & $4.09^{b}$ \\
\hline \multirow[t]{2}{*}{ Soil moisture } & Pulse & $6.09^{b}$ & $7.99^{\mathrm{b}}$ \\
\hline & Inter-pulse & - & $3.46^{\mathrm{b}}$ \\
\hline \multirow[t]{2}{*}{ Relative coverage score } & Pulse & $4.20^{b}$ & $4.49^{\mathrm{b}}$ \\
\hline & Inter-pulse & - & $0.75^{N S}$ \\
\hline \multirow[t]{2}{*}{ Revised SQI } & Pulse & $5.51^{\mathrm{b}}$ & $3.25^{\mathrm{b}}$ \\
\hline & Inter-pulse & & $0.121^{\text {NS }}$ \\
\hline \multirow[t]{2}{*}{ Herbaceous component score } & Pulse & $3.60^{b}$ & $3.92^{\mathrm{b}}$ \\
\hline & Inter-pulse & & $0.75^{N S}$ \\
\hline \multirow[t]{2}{*}{ EMV } & Pulse & $12.62^{b}$ & $14.39^{b}$ \\
\hline & Inter-pulse & & $0.23^{N S}$ \\
\hline \multirow[t]{2}{*}{ Land status } & Pulse & $16.50^{\mathrm{b}}$ & $10.54^{b}$ \\
\hline & Inter-pulse & & $0.56^{\text {NS }}$ \\
\hline
\end{tabular}

t-critical one tail and two tail are $1.79^{\mathrm{a}}$ and $2.20^{\mathrm{b}}$, respectively

inter-pulse and non-pulse indicated the changes in land qualities with high resource condition to medium and high to low resource conditions but not during medium to low resource stage. These results further funnel our knowledge recommending to avoid solitary land assessment approach.

\section{Ecological relevance of indicators}

The fraction of $\mathrm{RCD}$ and $\mathrm{BP}_{\text {modified }}$ are the two attributes of RCS, and in this, RCD was constructed with two attributes, i.e., community dynamics (quantitative) and litter conditions (LC) and removal of plant parts (RPP) which were qualitative in nature. Litter illustrated ecological dynamics and complexities, and the requirement for a range of cycles and states, within and between vegetation types, and it also play a major role in surface soil stability and structure. Irrespective of its microbial degradation, LC and RPP can be considered as associated parameters. Furthermore, grazing intensity is also an influential factor for LC which also held back by density of unpalatable species (DUP), and the relationship between GI and DUP are presented in herbaceous component score (HCS) index which is in agreement of Loydi et al. (2013) study.

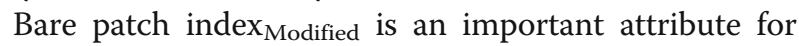
assessing arid lands status. Wind and water erosion activities are generally greatest in such patches resultant in resource loss. Therefore, bare patch size, by virtue of its direct relation with resource loss, is probably one of the best indicators of land health. In the present study, 
temporal analysis of this parameter revealed that during pulse event and at most of the lands, bare patches were not inter-connected (thus multiplication factor of 0.5), while obviously, its sizes increase during non-pulse event with higher connectivity (lack of vegetation cover).

There are two perspectives to use such information, i.e., species coverage area and identification of those species that are efficient to serve as a gap filler. In arid region, a gap filler species should have high energy efficiency and good sand binder property and can compensate one ecosystem service in the absence of others (i.e., may be unpalatable but having other provisional services like fiber, medicines, fuel, etc.). From this region, Mathur (2014) have recommended Corchorus depressus for wasteland management and rehabilitation as it has high energy utilization efficiency and high reproductive capacity enabling it to occupy more niche space, palatability, and good sand binding capacity. We found non-linear power relationship between bare patch index and species richness. We can visualize that when this index is below 7.0, at most of the lands, species richness ranged 7 or above. We also found a hump-back relationship between these two variables which suggested that with 0.2 to 6.0 bare patch index, richness increase from 5 to 8 , but when it ranged 23 to 37, richness decreased and it dropped to 2 . The causes of such relationships may vary with habitat and land use; however, most related factors involve grazing intensity, site slope, and soil factors (Maestre 2004 and Aguirre-Gutierrez 2014).

We found linear negative relationships between HCS and revised SQI. In our study, we have six components in HCS, viz, total herbaceous biomass, botanical species composition of climax vegetation, RIV of climax species, carrying capacity, grazing intensity, and density of unpalatable species, and among them, DUP was utilized as the denominator. Thus, negative relationships of HCS with SQI suggest an increase in DUP at study sites. Yamada and Takatsuki (2015) have also correlated the impact of grazers and unpalatable species on forest productivity, and they concluded several patterns of direct and indirect effects of these variables on productivity at Larch forest in Okutama, Japan.

Carrying capacity can be determined by experience gained over the years or by calculating long-term forage yields for the pasture, if possible. This information can help to predict how heavily a pasture can be stocked. In this study, rating for carrying capacity was based on the fact that when forage production declines by 50 , the degradation is only slight because such vegetation seems to have potential to quickly recover and regain optimum biomass production potential upon protection or optimum use. It is pertinent to consider here the situation prevailing in woodlands and shrub-lands where besides grazing, browsing and cutting also take place. There are two situations: (a) the current year's production is not fully utilized, thereby resulting in biomass build up even if $50-65 \%$ of current year's biomass is removed, and removal beyond this, there should cause degradation; and (b) the current year's production or more is fully utilized resulting in poor regeneration and decline in biomass over the years.

Several processes have been put forth explaining the deterministic control over soil fertility and species diversity (Bashkin et al. 2003). Inverse relationships of SOC, $\mathrm{K}, \mathrm{CEC}$, and soil fertility factors with herbaceous species richness and their biomass were explained by Wang et al. (2007; 2011) and Nadeau and Sullivan (2015). Soil organic matter and nitrogen significantly fluctuate with response to climatic conditions specifically temperature and rainfall (Rathore et al. 2012). In hot arid and semi-arid soils, organic matter rapidly decomposes in response of elevated temperature and thus increasing the organic carbon content. For Indian arid soils, depth vies logarithmic increase in soil organic matter content at a constant temperature which was reported by Mathur and Sundaramoorthy (2008). Additionally, vegetation, soil texture, drainage, cultivation, and fallowing also significantly influence the soil organic matter (Kumar and Mathur 2014). In this study, the negative relationships of soil organic carbon with species richness can be explained with facts that during pulse and inter-pulse events, low temperature and high moisture slow down the organic matter decomposition resultant in low organic carbon content; however, both these factors favored for high productivity and for diversity.

\section{Land behaviors and implications}

On the basis of this new approach, among 36 observations (12 lands during each event) $7,14,12$, and 3 lands were designated as lower, moderate, high, and very high value, respectively. This classification was based on land status index score which was ranged 1.23 to 2.15 during pulse and 1.26 to 2.09 and 1 to 2.37 during inter-pulse and non-pulse events, respectively. Land numbers 11, 4, and 6 were designated as very high value, while lands $3,6,7$, and 9 were marked for high value during pulse and inter-pulse events; however, land 8 showed continuous improvement from lower during pulse to moderate (interpulse) and high value (non-pulse). On the other hand, land number 11 showed degradation from high value (pulse) to moderate during inter-pulse and non-pulse. Such result suggested that, although in arid region, rainfall triggers community composition; however, sole use of this parameter cannot provide the correct status of lands as other physical (soil) and biotic (livestock and other anthropogenic) parameters are equally important and influential during other events. 
Thus, a combined approach to temporal assessment schedule can provide the perfect situation. Further, this was also proved by PCA bio-plot (Fig. 2) which was constructed with using different indices. Bi-plot suggested that (a) lands 1 and 4, 6 and 9, and 8 and 12 during pulse event showed proximity to each other, while during non-pulse events, they were located far away from each other; (b) lands 11 and 12 were opposite to each other during pulse events only and showed similarity and proximity with each other during inter- and non-pulse events; and (c) lands 2 and 8 during pulse and non-pulse events were located on opposite sides, however, showed closeness with each other during inter-pulse event, and lands 3 and 4 are always situated opposite to each other. Thus, for an example, if a researcher visited land 8 during resourceful conditions (rainy season), he will designate this lands as low value land. Similarly, if he surveyed this during inter- or non-pulse events, he will regard this as moderate or high value land, respectively. Thus, land assessment in such areas should be sequential one.

Thus, hypothesis that pertains to this study, i.e., "a combined mathematical approach may assess the land quality more precisely than their individual use within Indian arid region, and temporal land assessments may have different interpretation than a single time assessment", is being sufficiently answered and provided a new insight about land quality assessment in the Indian arid region. Thus, the proposed approach proves a realistic land status, and this study differed from earlier efforts with relation to its temporal summation integrated with weighted biotic and abiotic variables. The practical implication of the present study also pertains to its studied indices which easily can be used at different eco-regions with application of local weighting factors.

\section{Conclusion}

In the present study, the status of Indian arid lands was assessed temporally using five new approaches which pertain to 22 different parameters. This integrated approach revealed that in this arid region where resources are releasing in different forms of events, temporal appraisals of land qualities may be more instructive than a solitary time evaluation. Weighted attributes, ordination, and path analysis enable this study as a prototype one that would have wide applicability for land evaluation in such vulnerable part of the world. However, as this study was temporally conducted in one direction (pulse-interpulse-non-pulse), reverse exploration would further broaden our insight about nature of land degradation and their resilience properties in the Indian arid region.

\section{Additional file}

Additional file 1: Figure S1. Location map of the study area. Figure S2. Frequency Class and their respective Distribution Frequency Value. (DOC $704 \mathrm{~kb}$ )

\begin{abstract}
Abbreviations

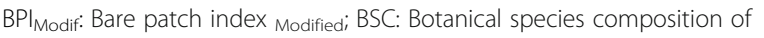
climax vegetation; C. Cap ACU/100 ha: Carrying capacity; DUP: Density of unpalatable species; E5: Evenness; EMV $V_{\text {Soil }}$ : Ecosystem monitoring value; Gl: Grazing intensity; HCS: Herbaceous component score; LC: Litter conditions; RCD: Relative community diversity; RCS: Relative coverage score; RIV of C. spp.: Relative importance value of climax species; RPP: Removal of plant parts; SDI: Shannon and Weaver diversity index; SQI: Soil quality index; SR: Species richness; THB: Total herbaceous biomass; $V_{C}$ : Value of ecosystem carbon sequestration; $V_{\mathrm{N}}$ : Value of ecosystem nitrogen sequestration
\end{abstract}

\section{Acknowledgements}

The authors are grateful to the Director of CAZRI (for study leave). We sincerely thankful to UGC-CAS, DST-FIST for financial support to the Department of Botany of JNV University.

\section{Ethical approval}

Not Applicable

Funding

Not available for this work.

\section{Availability of data and materials}

All data generated or analysed during this study are included in this published article (and its Additional file 1).

\section{Authors' contributions}

MM collected the data, and participated in the data analysis and drafted manuscript write-up and revision. SS designed the study, data interpretation, and manuscript write-up.

\section{Consent for publication \\ Not Applicable}

\section{Competing interests}

The authors declare that they have no competing interests.

\section{Publisher's Note}

Springer Nature remains neutral with regard to jurisdictional claims in published maps and institutional affiliations.

Received: 4 September 2018 Accepted: 15 November 2018

Published online: 28 December 2018

\section{References}

Aguirre-Gutierrez J (2014) Are plant species richness and diversity influenced by fragmentation at a micro scale? Int J Biodivers 9. https://doi.org/10.1155/ 2014/384698.

Allen SE, Grimshaw HM, Parkinson JA, Quarmby C, Roberts JD (1976) In: Chapman SB (ed) Chemical analysis in methods of plant ecology. Blackwell Scientific Publications, Oxford, pp 536-537.

Andrade BO, Koch C, Boldrini IIM, Velez-Martin E, Hasenack H, Herman JM, Kollmann J, Pillar VD, Overbeck GE (2015) Grassland degradation and restoration: a conceptual framework of stages and thresholds illustrated by southern Brazilian Grasslands. Brazilian J Nat Conser 13:95-104. https://doi. org/10.1016/j.ncon.2015.08.002.

Andrews SS, Mitchell JP, Mancinelli R, Karlen DL, Hartz TK, Horwath WR, Pettgrove GS, Scow KM, Munk DS (2002) On-farm assessment of soil quality in California's central valley. Agron J 94:12-23. https://doi.org/10.1071/SR14245.

Bashkin M, Stohlgren TJ, Otsuki Y, Lee M, Evangelista P, Belnap J (2003) Soil characteristics and plant exotic species invasions in the Grand Staircase Escalante National Monument, Utah, USA. Appl Soil Ecol 22:67-77. https:// doi.org/10.1016/S0929-1393(02)00108-7. 
Bhattarai KR, Vetaas OR, Grytnes JA (2004) Relationship between plant species richness and biomass in arid sub-alpine grassland of the central Himalayas Nepal. Folia Geobot 39:57-71 http://folk.uib.no/nboov/FoliaKRB-OREV-JAG.pdf.

Black CA (1965) Methods of soil analysis: Part I Physical and mineralogical properties. American Society of Agronomy, Madison, Wisconsin.

Casson N, Downes S, Harris A (2009) Native vegetation condition assessment and monitoring manual for Western Australia. Department of Environment and Conservation, Australian Government. P. 407. https://www.dpaw.wa.gov.au/ images/documents/plants-animals/monitoring/native_vegetation_condition_ manual_full.pdf.

Catling PC, Burt RJ (1995) Studies of the ground-dwelling mammals of eucalypt forests in south-eastern New South Wales: the effect of habitat variables on distribution and abundance. Wildlife Res 22:271-288. https://doi.org/10.1071/WR9950271.

Cosgrove D, Undersander D, Cropper JB (2001) Guide to Pasture Condition Scoring. Ft. Worth, TX: USDA Natural Resources Conservation Service Grazing Lands Technical Institute. https://scforage.org/wp-content/uploads/2018/05/ PastureConditionScoring.pdf.

D'Odorico P, Ravi S (2016) Land degradation and environmental change biol environ hazards, risks disasters, pp 219-227.

de Soyza AG, Van Zee JW, Whitford WG, Neale A, Tallent-Hallsel N, Herrck EJ، Havstad KM (2000) Indicators of great basin rangeland health. J Arid Environ 45:289-304. https://doi.org/10.1006/jare.2000.0645.

Eyre TJ, Kelly AL, Neldner VJ (2006) BioCondition: a terrestrial vegetation condition assessment tool for biodiversity in Queensland. Field assessment manual. Version 1.5. Environmental Protection Agency, Biodiversity Sciences unit, Brisbane https://www.qld.gov.au/__data/assets/pdf_file/0029/68726/ biocondition-assessment-manual.pdf.

Gibbons P, Ayers D, Seddon J, Doyle S, Briggs S (2005) BioMetric. Version 1.8. A Terrestrial Biodiversity Assessment Tool for the NSW Property Vegetation Plan Developer Operational Manual, Canberra https://www.environment.nsw.gov. au/resources/nature/NVAT_Biometric_manual_2.pdf.

Gotelli N, Chao A (2013) Measuring and estimating species richness, species diversity, and biotic similarity from sampling data. Encyclopaedia of biodiversity 5:195-211. https://doi.org/10.1016/B978-012-384719-5.00424-X.

Guntinas ME, Leiros MC, Trasar-Cepeda C, Gil-Sotres F (2012) Effect of moisture and temperature on net soil nitrogen mineralization: a laboratory study. Euro J Soil Biol 48:73-80.

Iwara Al, Ogundele FO, Ibor UW, Deekor TN (2011) Multivariate analysis of soil vegetation interrelationships in a south - southern secondary forest of Nigeria. Int J Biol 3:73-82 DOl:10.1.1.929.834 \&rep=rep1\&type=pdf.

Jackson ML (1973) Soil chemical analysis. Prentice Hall Inc. https://archive.org/ details/soilchemicalanal030843mbp.

Jafari R, Bakhshandehmehr L (2013) Quantitative mapping and assessment of environmentally sensitive areas to desertification in central Iran. Land Degrad Dev 27(2):108-119. https://doi.org/10.1002/ldr.2227.

Jansen A, Robertson A, Thompson L, Wilson A (2004) Development and application of a method for the rapid appraisal of riparian condition. River and Riparian Land Management Technical Guideline 4:1-14 https://library. dbca.wa.gov.au/static/FullTextFiles/069633.pdf.

Kent M, Coker P (1992) Vegetation description and analysis. A practical approach Belhaven Press, London 363 pp.

Kumar S (1992) Assessment of vegetation degradation status of methodological research. Ann of Arid Zone 31:53-62.

Kumar S, Mathur M (2014) Impact of invasion by Prosopis juliflora on plant communities in arid grazing lands. Trop Ecol 55L:33-47 http://tropecol.com/ pdf/open/PDF_55_1/03-Kumar\%20\&\%20Mathur.pdf.

Legendre P, Legendre L (1998) Numerical ecology. Second edition. Elsevier, Netherland, p 845.

Li S, Wang Q, Jing Z, Wang W (2009) The effects of protective enclosure on vegetation diversity, and productivity of degraded alpine Kobresia meadow (Quinghai-Tibetan Plateau). Polish J Ecol 57(3):495-502.

Lin CF, Chen ZQ, Xue QH, Lai HX, Chen LS (2007) Effect of Vegetation degradation on soil nutrients and micro flora in the Sanjiangyuan Region of Qinghai, China. Chinese J Appl Environ Biol 13:788-793 https://eurekamag. com/research/020/929/020929221.php.

Liu Y, Zha Y, Gao J, Ni S (2004) Assessment of grassland degradation near Lake Qinghai, West China, using Landsat TM and in situ reflectance spectra data. Int J Remote Sens 25(20):4177-4189. https://doi.org/10.1080/ 01431160410001680419.
Loydi A, Ecksten RL, Otte A, Donath TW (2013) Effects of litter on seedling establishment in natural and semi-natural grasslands: a meta-analysis. J Ecol 101:454-464.

Ludwig JA, Reynolds JF (1999) Statistical ecology, a primary methods and computing. John Wiley and Sons, New York, p 337.

Maestre FT (2004) On the importance of patch attributes, environmental factors and past human impacts as determinants of perennial plant species richness and diversity in Mediterranean semiarid steppes. Diversity and Distribution $10: 21-29$.

Mahdavi M, Jouri MH, Askarizadeh D, Salarian T, Miarrostami S (2013) Can the rangelands health model interpret the function of semi-steppe area (Iran)? International Journal of Agriculture and Crop Sciences 6(17):1227-1234.

Mandal D, Singh R, Dhyani SK, Dhyani BL (2010) Landscape and land use effects on soil resources in a Himalayan watershed. Catenax 81:203-208. https://doi. org/10.1016/j.catena.2010.03.004.

Masoudi M (2014) Risk assessment of vegetation degradation using GIS. JAST 16: 1711-1722 http://mbd.modares.ac.ir/article-23-6948-en.pdf.

Masoudi M, Amiri E (2015) A new model for hazard evaluation of vegetation degradation using DPSIR framework, a case study: Sadra Region, Iran. Polish J Ecol 63:1-9. https://doi.org/10.5141/ecoenv.2013.006.

Masoudi M, Patwardhan AM, Gore SD (2006) A new methodology for producing of risk maps of soil salinity, case study: Payab Basin, Iran. Journal of Appl Sci Manag 10(3):9-13. https://doi.org/10.4314/jasem.v10i3.17312.

Mathur M (2014) Functional dynamics of energy variables and their impacts on growth and population attributes of a woody perennial at arid wasteland. Australian J Bot 62:490-498. https://doi.org/10.1071/BT14180.

Mathur M (2015) Assessment of stand types of phosphorus-acquisition and internal utilization efficiency in a desert plant Blepharis sindica (T. Andres). Arid Ecosystem 5(2):102-111. https://doi.org/10.1134/S2079096115020079.

Mathur M, Sundaramoorthy S (2008) Distribution pattern and growth assessment of Corchorus depressus in semi arid Indian desert. Trop Ecol 49:69-71 http:// www.tropecol.com/pdf/open/PDF_49_1/07\%20Mathur.pdf.

Mathur M, Sundaramoorthy S (2016) Patterns of herbaceous species richness and productivity along gradients of soil moisture and nutrients in the Indian Thar Desert. J Arid Environ 125:80-87. https://doi.org/10.1016/j.jaridenv.2015.10.011.

McGranahan DA, Engle DM, Fuhlendorf SD, Miller JR, Debinski DM (2013) Multivariate analysis of rangeland vegetation and soil organic carbon describes degradation, informs restoration and conservation. Land 2:328-350. https://doi.org/10.3390/land2030328.

Miao L, Moore JC, Zeng F, Lei J, Ding J, He B, Cui X (2015) Footprint of research in desertification management in China. Land Degrad Dev 26(5):450-457. https://doi.org/10.1002/ldr.2399.

Nadeau MB, Sullivan TP (2015) Relationships between plant biodiversity and soil fertility in a mature tropical forest, Costa Rica. Int J For Res. https://doi.org/10. 1155/2015/732946.

Narita K, Wada N (1998) Ecological significance of aerial seed pool of a desert lignified annual,Blepharis sindica (Acanthaceae). Plant Ecol 135:177-184. https://doi.org/10.1023/A:1009713512472.

Oliver I, Parkes D (2003) A prototype toolkit for scoring the biodiversity benefits (and disbenefits) of landuse change. Version 5. Department of Land and Water Conservation, Sydney http://moderncms.ecosystemmarketplace.com/ repository/moderncms_documents/biodiversity_toolkit.pdf.

Padilla FM, Miranda JD, Armas C, Pugnaire FI (2015) Effects of changes in rainfall amount and pattern on root dynamics in an arid scrubland. J Arid Environ 114:49-53.

Pandeya SC, Puri GS, Singh JS (1968) Research methods in plant ecology. Asia Publishing House, London.

Parkes D, Newell G, Cheal D (2003) Assessing the quality of native vegetation: the habitat hectares approach. Ecol Manage Restor 4:29-39 https://www.foresttrends.org/wp-content/uploads/imported/4assessing-quality-of-nativevegetation-d-parkes-pdf.pdf.

Pyke DA, Herrick JE, Shaver P, Pellant M (2002) Rangeland health attributes and indicators for qualitative assessment. J Range Manag 55:584-597 https://pdfs. semanticscholar.org/a4ff/3aa62f5b15946f76143f1148143e0e5b5471.pdf.

Qiu L, Wei X, Zhang X, Cheng J (2013) Ecosystem carbon nitrogen accumulation after grazing exclusion in semiarid grassland. PLoS One 8(1):e55433. https:// doi.org/10.1371/journal.pone.0055433.

Rathore VS, Santra P, Birbal S, Nathawat NS (2012) Crop water productivity, needs and techniques. In: Symposium on managing stress in dry-lands under climate change scenarios, arid zone research Association of India. December 1e2, pp 33-36. 
Salim M, Kumar P, Gupta MK, Kumar S (2015) Seasonal variation in some chemical characteristics of the soil under different land uses of Jhilmil Jhee wetland, Haridwar-Uttrakhand, India. Int J Sci Res 5(10):1-9.

Saxena SK, Aggarwal RK (1983) Primary productivity and nutrient composition of desert grasses from a common habitat II Grass species. Indian J Ecol 12:205-208.

Stern NL (2013) Carbon pricing: analyzing the issues that matter to the clean revolution. The Clean Climate Group:1-9 https://www. theclimategroup.org/sites/default/files/archive/files/May-Insight-Briefing--Carbon-Pricing.pdf.

UNCCD (2012) Zero Net Land Degradation: A New Sustainable Development Goal for Rio Page 30. http://www.droughtmanagement.info/literature/ UNCCD_zero_net_land_degradation_2012.pdf.

UNEP (2007) Land. Nairobi, Kenya: United Nations Environment Programme (UNEP).

Vieira RMSP, Tomasella J, Alvala RCS, Sestini MF, Affonso AG, Rodriguez DA, Barbosa AA, APMA C, Valles GF, Crepani E, de SBP O, de MSB S, Calil PM, de Carvalho MA, Valeriano DM, FCB C, Santana MO (2015) Identifying areas susceptible to desertification in the Brazilian northeast. Solid Earth 6:347-360. https://doi.org/10.5194/se-6-347-2015.

Wang C, Wang G, Liu W, Wu P (2011) The effect of plant soil-enzyme interactions on plant composition, biomass and diversity of alpine meadows in QuingnaiTibetan Plateau. International J Ecol. https://doi.org/10.1155/2011/180926.

Wang CT, Long RJ, Wang QJ, Ding LM, Wang MP (2007) Effect of altitude on plant-species diversity and productivity in an alpine meadow QinghaiTibetan Plateau. Australian J Bot 55:110e117 https://pdfs.semanticscholar.org/ 715e/061fc6af2904ecc859b14210ddcef41bc766.pdf.

Wei-Giang L, Xiao-Jing L, Ajmal K, Bilquees G (2008) Relationships between soil characteristics and halophytic vegetation in coastal region of North China. Pak J Bot 403:1081e1090 http://citeseerx.ist.psu.edu/viewdoc/download?doi= 10.1.1.530.9520\&rep=rep1\&type $=$ pdf.

Wen L, Dong S, Li Y, Li X, Shi J, Wang Y, Liu D, Ma Y (2013) Effect of degradation intensity on grassland ecosystem services in the alpine region of QinghaiTibetan Plateau, China. PLoS One 8(3):e58432. https://doi.org/10.1371/journal. pone.0058432.

Wen L, Dong SK, Zhu L, Li XY, Shi JJ, Wang YL, Ma YS (2010) The construction of grassland degradation index for alpine meadow in Qinghai-Tibetan Plateau. Procedia Environ Sci 2:1966-1969. https://doi.org/10.1016/j.proenv.2010.10.210.

Xie LW, Zhong J, Chen FF, Cao FX, Li JJ, Wu LC (2015) Evaluation of soil fertility in the succession of karst rocky desertification using principal component analysis. Solid Earth 6:515-534

Yamada H, Takatsuki S (2015) Effects of deer grazing on vegetation and ground dwelling insects in a larch forest in Okutama, Western Tokyo. Int J For Res. https://doi.org/10.1155/2015/687506.

Zhang J, Zhao H, Zhang T, Zhao X, Drake S (2005) Community succession along a chronosequence of vegetation restoration on sand dunes in Horqin Sandy Land. J Arid Environ 62:555-566. https://doi.org/10.1016/j.jaridenv.2005.01.016.

\section{Submit your manuscript to a SpringerOpen ${ }^{\odot}$ journal and benefit from:}

- Convenient online submission

- Rigorous peer review

- Open access: articles freely available online

- High visibility within the field

- Retaining the copyright to your article

Submit your next manuscript at $\boldsymbol{\nabla}$ springeropen.com 